\title{
A KOMPUTER ÁLTAL LÉTREHOZOTT VIRTUÁLIS VALÓSÁG PSZICHOLÓGIAI MECHANIZMUSAI: TÉRI REPREZENTÁCIÓS SAJÁTOSSÁGOK
}

\author{
KÁLLAI JÁNOS ${ }^{1,2}$ \\ ${ }^{1}$ Pécsi Tudományegyetem, Általános Orvostudományi Kar, Magatartástudományi Intézet \\ ${ }^{2}$ Pécsi Tudományegyetem, Bölcsészettudományi Kar, Pszichológiai Intézet, \\ Személyiség- és Egészségpszichológia Tanszék \\ E-mail: janos.kallai@aok.pte.hu
}

Beérkezett: 2018. november 7. - Elfogadva: 2019. február 7.

\begin{abstract}
A virtuális valóságban (VR) végzett gyógyászati és oktatási tevékenység iránt megnövekedett érdeklōdés szükségessé teszi a VR-re vonatkozó pszichológiai értelmezési keretek egy csoportjának bemutatását. Az összefoglalóban - szakirodalmi ismeretekre hagyatkozva - a belemerülés (immersion), valamint a jelenlét (presence) fogalmak rövid bemutatását követôen a virtuális valóság mentális modelljei közül elsôsorban a téri reprezentációra vonatkozó komponenseket fogom bemutatni. Az áttekintés a VR-ben megjelenô multiszenzoros koherencia, tudatos jelenlét, kapcsolat és leválás, átmeneti jelenlét és a különbözô affordanciák szerepének ismertetésére koncentrál. Az alkalmazások fejezetrészben pedig néhány, az egészségügyben és az oktatásügyben alkalmazott, és várhatóan az eddigi gyakorlathoz viszonyítva szélesebb körben hazánkban is alkalmazandó VR-alapú eljárások ismertetésére kerül sor. A digitális oktatás és a pszichoterápiás ellátás iránti érdeklōdés ellentmondásos. Sokan a klienssel vagy a tanulóval való személyes kapcsolat elvesztésének fenyegetố veszélyétól féltik az orvosokat és a pedagógusokat. A betegek és a diákok részéról azonban egyre sürgetóbb az igény a VR-hez kötődô módszerek bevezetésére. A bemutatott összefoglaló tovább erôsíti az új digitális eszközök alkalmazásával kapcsolatos igényeket, de ugyanakkor felhívja a figyelmet, hogy szükség van olyan technikai és szaktudományi infrastruktúra megteremtésére, amely kritikus elemzést követôen képes elösegíteni a jelenlegi, konfliktusokkal terhes ellátási és oktatási formák fejlōdését. Az új VR-módszerek bevezetése a tudomány és a gyakorlat közös feladata.
\end{abstract}

Kulcsszavak: belemerülés, motivált jelenlét, multimodális integráció, affordancia, Próteusz-effektus 


\section{BEVEZETÉS}

A nagy mennyiségú adat gyors feldolgozására kifejlesztett, programozott elektromos készüléket, a komputert, alkalmazásának kezdeti idôszakában a szellemi tevékenység határait kibővítô és a problémamegoldási lehetôségeket kiegészítô eszköznek tartották. A számítógép hibák, érzelmi hatások, személyes diszpozíciók zavaró hatása nélkül végzi a programozó által elóírt feladatokat. Monitorokkal, nyomtatókkal, interface-kártyákkal kiegészülve különböző robotizálható tevékenységeket vezérel, vagy a folyamat különbözô szakaszait visszajelentô szenzorokon keresztül szabályozza a gyártási folyamatot, a munkatevékenység egyes szakaszait. Napjainkra a helyhez kötött, valamint a mobilizálható digitális eszközök a mindennapi életvitel és a szórakozás részévé váltak. A programnyelvi utasítások rendszerét több helyen leváltották az utasításcsomagokat tartalmazó ikonok. A billentyüzettel és a képernyőn mozgó kurzor irányításával, személyes tartalmak és célok megvalósításán keresztül közvetlen, személyes viszony alakult ki a komputer és az ember között. A kompetens eszközhasználathoz, a célok megvalósítását segítő technikai berendezések múködtetéséhez - személygépkocsi, munkaeszközök, játékok - hasonlóan számos személyes érzés (pl. siker, boszszúság) kapcsolódott. A képernyoon megjelenô tartalmak kezelése, a komputer által irányított berendezések felügyelete, a munka, a játék vagy bármely más alkalmazási forma megkívánta a komputer által modellezett valós környezet különbözó modalitású ingereinek felfogására alkalmas szenzorokkal való kibővítést. A fokozatosan fejlôdô digitális grafikai ábrázolás és háromdimenziós megjelenítés, a fejre szerelhetô, a fej és késôbb a test és kéz pozícióját és mozgását regisztráló háromdimenziós képernyôk és mozgáskövetô szenzorok kidolgozása (HMD) ${ }^{1}$ lehetôvé tette a digitálisan létrehozott valóságélmény elmélyítését (Burdea és Coiffet, 2003). A virtuális valóság (virtual reality, VR) egy, a megjelenésének kezdeti idôszakából származó meghatározás szerint (Ellis, 1991) egy komputer által létrehozott mesterséges környezet, melyben az oda belépô személy a szenzoros ingerek mintázatát ideiglenesen létrehozott környezetként értelmezi, mely eltér az ôt magába foglaló fizikai környezettôl. Napjainkra a virtuális környezetet (virtual environment, VE) megjelenítô technikai berendezések személyes jelenlétérzéssel kísért valóságélmény kiváltására képesek. A VR lényegében egy, a környezetértelmezésre vonatkozó digitális technikára alapozott alternatíva. Hagyományos alkalmazási körülmények között a belemerüló személy dönti el, hogy él-e, és ha igen, milyen mértékben ezzel a lehetôséggel. A VR definíciója három fố komponenst emel ki: a VR (a) ideiglenes, (b) a fizikai környezet téri és idối dimenziói foglalják magukba, (c) a résztvevô döntései tartják fenn és motiválják a benne végzett tevékenységet. A modern készülékek a belemerülés lehetôségét olyan szintre emelték, melyben az átélt VR-élmény intenzitása a fizikai valóságban szerezhetô élményekkel szinte azonos érzéseket vált ki. A VR-ben, a multimodális ingermintázat kongruenciája által előállított háromdimenziós világban a virtuális valóság és az abban aktívan tevékenykedô személy között közvetlen interakció van. A képernyốn megjelenített események - részben a filmnézés attitûdjéhez hasonlóan - egy-egy epizódsort ábrázolnak, függetlenül attól, hogy a történés realitását közvetlen fizikai jelenlét hiányában 
ellenôrizni tudjuk-e, vagy sem. ${ }^{2}$ A fizikai valóságtól elhatároló felületekkel, a szem elé felszerelt miniatûr képernyôvel (head mounted display, HMD) elválasztott virtuális látótérben történô események hitelesítése egyrészt a programozó manipulációin és a belemerülést segítô technikai feltételek minôségén múlik. A személyes részvételre vonatkozó döntés, a kétkedéssel járó fokozott valóságkontroll, az információ megbízhatóságának ellenốrzési folyamata a pszichológiai kutatási témakörök alatt tárgyalt jelenségek. ${ }^{3}$ Az alkalmazás mindennapi gyakorlata rámutatott arra, hogy a komputer és az ember interakciójának realitástartalma, a jelenlétérzés növelése a multimodális ingerek szisztematikus alkalmazásával fokozható (Gentile, Petkova és Ehrsson, 2011). A technikai fejlesztések a valóságélményt fokozó szenzorokat, auditív hatásokat, a látottakkal együtt megjelenô fizikai mozgásokat kísérô fény- és hangeffektusokat, késôbb pedig konkrét, összetett fizikai mozgásokat is követố vesztibuláris ingerekre támaszkodó szimulátorokat is kialakítottak. Ezek a valóságszimulátorok lemásolják egyes mindennapi tevékenységek lépéseit, és eredményesen alkalmazhatók képességfejlesztésben, munkafolyamatok gyakoroltatásában. ${ }^{4}$ Napjainkra a komputer által generált valóságélményt érzékeny ingerfelvevô készülékekkel fokozzák, és az adott pillanatban kibôvítik a virtuális környezet (VE) érzékelésének lehetôségeit (augmented reality). Nemcsak ábrázolják, de a valós környezetben tevékenykedô számára új, korábban vagy a késôbbiekben valószínúleg bekövetkezô információk is kikerülnek az alkalmazott miniatûr kivetítôkre (mixed reality). A képernyô pixelsûrúsége, a kép dinamikája, a színek természetessége, az alakok élethúsége, a hang és a mozdulat szinkronja, az interakció technikai megbízhatósága, az emberi képességeket néha túlszárnyaló mozgási lehetôségek bevonják a résztvevốt ebbe a világba. A belépés személyes döntésen múlik. Amennyiben az alkalmazó várakozásai teljesülnek, elmerül (immersion), eggyé válik a virtuális környezettel, mint ahogy ezt a mindennapi körülmények között a valóságos környezetével kapcsolatban is megteszi. ${ }^{5}$ A belemerülés mélységét leginkább a technikai feltételek minősége határozza meg (Slater és Wilbur, 1997).

2 Világossá kell tennünk, hogy a komputertechnikai eszközökkel elôidézett jelenlétet mellôzô, helyileg távoli eseményrôl kapott híreket, vizuálisan megjelenített közvetítéseket a befogadó tájékozottsága szerint misztikus kinyilatkoztatásként, mítoszként, meseként, hazugságként vagy igazi, megtörtént eseményként egyaránt értelmezhetjük. A látott kép meggyőző ereje azonban a leírt vagy elbeszélt történetek valóságtartalmának megítéléséhez képest nagyobb. A templomok freskóin megjelenô vallásos ábrázolások jelentôs vizuális megerôsítôi voltak a hirdetett tanoknak. A vizualitás valóságteremtô erejét nehéz kétségbe vonni, még abban az esetben is, ha tudásunknak a látvány, a mutatvány, az illúzió tartalma ellentmond.

3 E tárgykör bemutatásának fejlôdéstörténetét kiváló mûvek foglalják össze (Bandura, 1986; Csibra és Gergely, 2013).

4 A szimulációban végzett tanulás és képességfejlesztô gyakorlatok anyagi és mentális hozadéka jelentôs, de a mozgás- és értelmi fogyatékossággal élô személyeknél, valamint pilótáknál tapasztalt rutinmegoldások elemzése rámutat, hogy számos dependencia és hibás megoldás miatt megfontoltan kell kezelnünk a virtuális valóságban szerzett tapasztalatok mindennapokra való átvitelét.

5 A viselkedés ökológiai természetét figyelembe véve a VR a feladat- és munkavégzés eszköze, mely a maga affordanciái (tevékenységi lehetôségei) alapján valóságos válaszokat eredményez. Ebben a megközelítésben a VR-be való belemerülés és a valóságos környezetbe való belemerülés egymásnak megfeleltethetố fogalmak. Amennyiben az akció kivitelezésére rendelkezésre áll az ingerkonstelláció, a megvalósításra pedig a megfelelő alkalom, valóságos válasznak kell megtörténnie. A VR tehát nem virtuális válaszokat, hanem valós, reális válaszokat és érzéseket eredményez. A kérdés azonban továbbra is nyitott: a VR milyen viszonyban van a valós környezet aktuális kihívásaival. 


\section{BELEMERÜLÉS}

A digitális eszközökkel kialakított mesterséges környezetbe való belemerülés (immersion) mértékét a technikai eszközök reakció- és felbontóképessége és az alkalmazott ingerek valósághú elrendezése határozza meg. A VR-be való belépés az esetek többségében a HMD felvételének következményeként tudatos döntés eredménye. A vállalkozó számít arra, hogy magával ragadó, a mindennapoktól részben eltérố törvényekkel rendelkezô világba lép. ${ }^{6}$ A VR által kínált törvények elfogadása, a szabályok átértékelése mellett affektív faktorok, személyes törekvések, a technikai rendszerekhez való viszony, kiszolgáltatottság vagy a felfedezôi kíváncsiság befolyásolja a személy VR-ben mutatott teljesítményét. Kérdés ugyanakkor, hogy a személy magára öltve a HMD-t, jelen van-e egyáltalán a VR-ben, nézôként vagy szereplooként tekint-e önmagára. A komputer által létrehozott virtuális környezetben a képernyó pixelfelbontási artikulációja, a képfelépítés gyorsasága, az alkalmazott ingerek vizuális kidolgozottsága, a térhatású ábrázolás, a perspektívabeállítás és az árnyékolás életszerúsége döntô fontosságú. A VR-ben a jelenetek észszerú felépítése, a kidolgozható perceptuális és válaszstratégiák fizikai lehetôségei, a jelenethez tartozó ingerek téri és idôi megjelenésének koherenciája a realitás megtévesztố hatását keltve magába vonzza a szemlélôt (Slater, 2002). A szemtôl néhány centiméter távolságban elhelyezett szemüvegmonitorok esetén a téri perspektíva feldolgozása jelentôs okulomotoros distresszt okoz, mely fóleg az alsó látótér letapogatása esetén fejfájást és homályos látást idézhet elô. Továbbá a vizuális referenciakeretek felvételekor a fókuszváltás technikai és mentális felfrissítése esetén megjelenô késedelem is megzavarhatja a belemerülést. Következményként a felhasználó testi pozíciója és a látvány által kínált szenzoros események között kellemetlen kísérőjelenségeket kiváltó konfliktus keletkezhet (Smart, Stoffregen és Bardy, 2002). Ezt a tengeribetegséghez hasonló állapotot (cybersickness) émelygés, szédülés, esetleges hányinger, fáradtság, apátia, testtartási bizonytalanság és orientációs zavarok kísérhetik. A tengeribetegségre hajlamos személyek egy jelentôs része kifejezetten érzékeny a mesterségesen létrehozott digitális környezet perceptuális anomáliáira. A VR használata közben gyakran élnek át cybersicknessre jellemzó tüneteket (Lawson, 2014).

A komputer által létrehozott virtuális valóságban való tudatos fizikai jelenlétérzés a valóságban való létezés igényének a közvetlen felfüggesztésével, a szkeptikus, kritikus valóságkontroll-stratégiák idôleges gátlásával jár. Vizsgáljuk meg részletesebben a VR-ben átélhetô fizikai jelenlétérzés tartalmát és forrásait.

\section{JELENLÉT}

A VR-ben való jelenlét (presence) általános értelemben a felhasználó személyes válasza a megjelenített történésekre, személyes vagy személytelen viszony az eseményekhez. A fizikai realitás és a virtuális realitás viszonya ismeretelméleti kérdés. A valóság különbözó megjelenési formáira vonatkozó kérdést most megkerüljük. Maradjunk a

6 A tudatos belépés nélküli automatikus immerziót hallucinációnak nevezhetjük, ugyanis a személyt megcsalják az érzékszervei, nem létezô dolgot létezônek tekint. 
megismerés pszichológiai terminusainál. A környezet érzékelése személyes tapasztalatokon múlik. A gondolataink kifejezésére alkalmas közös nyelvet fogalomkészlet, szerepek és szokások felvétele során kialakult sémák határozzák meg. Következésképpen a valóságészlelés a korábbi tapasztalatok során fokozatosan kialakult reprezentációkon múlik. A jelen percepciója, a pillanat, epizód, jelenet, a történések, az érzések megfogalmazása tehát különbözô ingerek, beállítódások, szükségletek, reflexek által kialakított csatornák által közvetített információk feldolgozása során alakul ki, természetesen meglehetôsen gyorsan, 20 milliszekundum és 300 milliszekundum, magasabb feldolgozási szint esetén akár több perc, óra vagy évtized leforgása alatt. Tehát a perceptuális rendszerünk adott határai között érzékelhetó valóságot nem közvetlenül, hanem a korábbi tapasztalataink alapján meghatározott reprezentációinkon keresztül érzékeljük. Következésképpen az ember számára a valóság közvetett formában elérhetô világ (remote reality).

A jelenlétnek több oldala van: közvetlen fizikai jelenlétérzés, a többi felhasználót is érintô szociális kapcsolataikra vonatkozó szociális jelenlétérzés vagy egy megtestesített, a belépô személlyel identikus képviselóvel való azonosságon keresztül átélt érzés keríti az embert a hatalmába. A VR-ben való jelenlétérzés a kilépést követôen vagy a benttartózkodás ideje alatt gyújtött kérdôívadatokon, interjúkon, vizuális-analóg skálákon keresztül, szenzomotoros koordináció regisztrációjával, valamint negatív vagy pozitív helyzetekben mért pszichofiziológiai reakciók mérésével térképezhetô fel (Insko, 2003). Az új, a nagyközönség számára is elérhetô VR-technológiák tömeges méretekben szolgálják az „ottlét” misztériumát. Egy mágikus trükkre van csupán szükség, feltenni a HMD-t, amely egy pillanat alatt játékkal, speciális munkafeladattal elfoglalt virtuális közösségbe röpít. Számos lehetôség közül választva, a megfelelô szoftver letöltésével máris a Föld túlsó oldalán lévô kiállítóterem tárgyai közé kerül a felhasználó. Az azonos virtuális térben lévô személyek közötti fizikai kontaktus lehetôsége nélkül szociális kapcsolatok szövődnek, bontakoznak ki vagy záródnak le. Ezekben a kapcsolatokban több esetben a szereplőnek nincs érvényes története, karakterének nincs állandósága, viselkedésének bizonytalan a validitása, a másokért érzett felelôsségvállalás a csoporttagok egy részéból hiányzik. Létezésük meseszerü, hol itt, hol ott bukkannak fel, különbözô arccal és eltérô szerepekkel. A virtuális térben való jelenlét, az érzelmi, morális és az általános szociális alkalmazkodási szabályokat követô tudatos énérvényesítés mértéke sokszor eltér a valóságban gyakorolt szokásoktól. Ilyen körülmények között a személyes identitás megjelenítése veszélyes, és sokszor lényegtelen is egyben (Slater, 2009).

A perceptuális rendszer szempontjából tehát az emberi gondolkodás fejlôdését jelzô határkövek, animizmus, mítoszok, hiedelemvilágok, folyamatosan átértékelt tudományos koncepciók egyértelmúen mutatják a valóságpercepció személyes jellegét. Megórizve az egyedi tapasztalatokban rejlô invarianciákat, emlôsök és humán egyedek vonatkozásában azonban olyan reprezentációs formákat tártak fel, melyek az agy anatómiai szerkezetében is azonosítható, különbözô területekhez köthetô funkciócsoportokat írnak le. A két legismertebb valóságreprezentációs forma, az allocentrikus és az egocentrikus (O’Keefe és Nadel, 1978), egyaránt figyelembe veszi a környezet fizikai és emberi vonatkozásait. Az elóbbi a környezetben zajló eseményeket az ember nézôpontjától, az adott pillanatban elfoglalt helyétôl és helyzetétôl független kognitív 
térben jeleníti meg. Az utóbbi pedig a referenciakeretet a személy adott idôben és térben elfoglalt helye alapján definiálja. Ez a két különbözố típusú reprezentációs forma lehetôséget ad a korábban felvetett kérdés elemzésére. Amennyiben a valóság közvetett, és nem a közvetlen reprezentációs modelljéből indulunk ki, egy idôben két különbözố típusú valóság jelenlétére is találunk bizonyítékot. Az egyik meghatározásban (allocentrikus) a személy testi jelenlétének nincs, a másikban viszont van (egocentrikus) jelentôsége. A két, egymással kapcsolatot keresố (juxtapozíció) ${ }^{7}$ és az esetek többségében együttmúködô reprezentáció megengedi az egymás mellett létezô valóságreprezentációk feltételezését. Amennyiben elfogadjuk ezt a lehetôséget, meg kell vizsgálnunk a közvetett módon elérhetố valóság két reprezentációs formájának kölcsönviszonyait és a szélsôséges pozícióba lendülés következményeit, azt az eshetôséget, amikor a személy csak saját szempontjából, más esetben pedig csak tôle független szempontok alapján van jelen a téri kontextusban. ${ }^{8}$

Az ottlét, „being there” kifejezi, hogy a személy egy adott környezet vagy szituáció koherens multimodális ingereinek hatása alatt áll, melyben fokozottan átéli saját testi jelenlétének élményét, intenzív kapcsolatban áll a környezetével, a történésekkel, a jelenetekkel, miközben figyelme a dolgok megismerésére, a feladatok megoldására és a helyzetben való tudatos és eredményes részvételre összpontosít. Részvételi attitúdje a mindennapi realitásban végzett éninvolvált feladatmegoldással megegyezô. A környezet egyik elemeként együtt él a történésekkel, a fizikai valóság fontos részeként azonosítja magát. Nem külsố szemlélố, nélkülözhetetlen része a virtuális környezetnek, melynek az adott pillanatban csak vele együtt van értéke, egyedi jelentése. Testileg (viscerális és proprioceptív ingeregyüttes érzékelésével) és lelkileg (kognitív folyamataira vonatkozóan önreflektív beállítódással) együtt él a VR világával. A VR tehát a résztvevốben olyan hatást kelt, mintha a fizikai tér egy fix pontjában helyezkedne el (spatial presence), stabilnak és egységesnek érzi saját testének felépítését (self-embodiment), valós interakcióban áll a virtuális környezetével (physical interaction), és a résztvevố más személyekkel tényleges kommunikációt folytat (Isselsteijn és Riva, 2003; Schubert, 2009). Következésképpen a világról alkotott kép, az allocentrikus környezeti reprezentációk ötvözôdnek

7 A 9-10 éves gyermekek valóságábrázolását a szemléleti realizmus jellemzi, de a 4-5 éves korú gyermekek számára az idô és tér fogalmak még csak utalásokon keresztül érvényesülnek. A konceptuálisan összetartozó alakok, formák összetett téri viszonyait (felette, mögötte, alatta, rajta, benne) az alakzatok montázsszerû egymás mellé rendelésével ábrázolja (juxtapozícióba helyezi). A tapasztalat szerint érzékeli, hogy bizonyos részek összetartoznak (fej, láb, kéz), de az összetartozás mibenlétének téri viszonyait nem definiálja. Ebben az idôszakban még a szinkretizmus, az élményvezérelt tapasztalat idôi-téri egysége érvényesül, a történés vagy a vizuális jelenetek belsô rendjének differenciált megfogalmazása nélkül. A szinkretizmus és a juxtapozíció szemléleti küzdelmében a realizmus mint döntôbíró nem játszik még lényeges szerepet (Piaget, 2002).

8 A fizikailag valós és a virtuális valóság kifejezések természetszerûen nem fedik le az ideiglenesen létezô vagy más formában megjelenô valóságok széles skáláját. A mese, a tévhit, a színházi élmény, a múvészi alkotásban való elmélyedés, a pszichózis világa számos alkalmat kínál a valóságból való hosszabb-rövidebb idôre történô kilépésre. Az alkalmi virtuális világokban való elmélyedésnek azonban megvan a rituáléja. Kivételt képez a pszichózis, melyben a személy nem ismeri fel, hogy a betegsége által kiváltott tévképzetek világában tartózkodik. A komputertechnológia által elôállított virtuális valóságnak azonban más esetekhez mérve rövid a kulturális története. Nem ismerjük még pontosan, hogy az interakcióknak, az együttélésnek, a virtuális valóságban szerzett ismereteknek milyen hatásuk van a személy mentális apparátusára, érzelmi életére, morális és viselkedéskontrolljának fejlôdésére. 
a személyközpontú egocentrikus reprezentációkkal. Ottléte megszemélyesíti ezt a helyet. Motivációs szempontból a hagyományos valóság törvényekre épülố világából egy másik, módosult szabályok szerint múködô világba való átlépés vágya hajtja a személyt a VR-be való belépésre, egy olyan világba, melyben a technikailag kifinomult eszközök és a szoftverkészítôk igényéhez alkalmazkodva valósítja meg önmagát. Lehetôségeinek bôvítése céljából módosítja a tudatállapotát. Számos biokémiai, fizikai, mentális és komputertechnikai eszköz áll ehhez rendelkezésre. Az élményekbe való belemerülés és a felfokozott jelenlétérzés a fokozott tudatosságélmény egyik kiemelkedô megjelenési formája. A jelenlét Wirth és mtsai, (2007) által kidolgozott kognitív teóriája szerint az ottlét idôszakában a személy egocentrikus szempontból észleli a világot, tudatában van önmaga jelenlétének és a körülvevố világban való részesedésének, de mindez nem zárja ki, hogy automatikus folyamatokkal részt vegyen a virtuális valóság mentális modelljének megszerkesztésében és fenntartásában. A jelenlétélmény tehát többé-kevésbé tudatos, de megzavarható. A VR-ben tapasztalt szenzoros élményekhez képest szokatlan, a fizikai realitásra jellemzó ingerek esetén (a kéz nekiütốdik a VR-nek helyet adó helyiség falának, vagy a szabad előrehaladás látványa ellenére a személy fizikai akadályba ütközik, megbotlik, esetleg egy idegen személy megzavarja a VR-ben folytatott tevékenységét) esetén a VR illúziója megtörik (break-in presence), és egy idônek el kell telnie, hogy kilépjen vagy visszazökkenjen a korábbi valós vagy virtuális környezetébe.

\section{A VIRTUÁLIS VALÓSÁG MENTÁLIS MODELLJÉNEK FÓ ALKOTÓELEMEI}

Tudatállapot tekintetében a virtuális valósághoz való viszonyulásnak számos fejlôdés-, kognitív, személyiség-lélektani összetevôje van. Az alábbi elemek elsôdleges megkülönböztetésére hívom itt fel a figyelmet.

\section{Multimodális ingerkoherencia}

Egy tárgy jelentése már a percepciója elôtt készen áll, csak a megfelelố ingerek együttállása szükséges ahhoz, hogy az adott pillanatban és téri kontextusban kiemelkedjen a lehetséges jelentéstartalmak sokaságából. Az idôi és téri kontextust - a droghatásoktól és pszichopatológiai állapotok kognitív következményeitôl eltekintve - kultúrától és nyelvhasználattól független fizikai szabályszerûségből adódó konszenzus kíséri. A konszenzus alapja a térben és idóben végzett személyes cselekvés, a belsô szervekben zajló biokémiai ritmusok, tónusos és fázisos állapotok, valamint a vázizomrendszer automatikus reflextevékenysége, melyek fejlôdését, erôsödését vagy háttérbe szorulását a fizikai és szociális ingerfeltételek szabályozzák. A koherens modális egység jelentésértéke azonban nem kategorikus, a jelentéstartamtól független szenzoros esemény gátolhatja vagy serkentheti a felszínre kerülését. A VR létrehozásához szükséges multiszenzoros integráció szerkesztése négy alapelvre épül. Ki kell emelni egy domináns modalitást, melynek megjelenésével azonos ritmusban jelenítünk meg más modalitású ingereket. Az optimális integráció érdekében az adott ingert meghatározott téri helyzethez kötjük. Érjük el, hogy a beszerkesztett inger a téri kontextusával együtt értelmes je- 
lentéstani egységet alkosson. Az inger és az ingerforrás kapcsolata legyen egyértelmú. Az alapelvek teljesülése esetén az integráció határozottan javítja a viselkedéses válasz hatékonyságát, ugyanakkor a gyenge vagy ellentmondásos ingerek rontják a multimodális integráció eredményét (Deroy, Faivre, Lunghi, Spence, Aller és Noppeney, 2016). A VR előállításának egyik legfontosabb alapelve a lehetséges jelentéstani egységbe vonható különbözó ingermodalitások idôben és térben szinkron megjelenítése. Minél gazdagabb és pontosabb a különbözô ingermodalitások szinkronmegjelenése, annál erôsebb hatású a valóságélmény.

\section{A tudatosság szintje}

A tudatosság szintje szerint az elsôdleges tudatosság (primary consciousness) a közvetlenül átélt, az esetek többségében spontán események által kiváltott élményekre vonatkozik, a reflektív tudatosság (reflective consciousness) azonban a saját élményeinkre adott válaszokból ered (Sas és O'Hare, 2003). A VR-ben való tudatos és sikeres részvétel - a mindennapi reális környezetben megszokott vélekedéseknek megfelelóen (Baron-Cohen, 2001) - feltételezi a szereplők, tárgyak, emberek, állatok tevékenységére vonatkozó szándékok, törekvések, szükségletek, karakterjegyek jelenlétét. ${ }^{9}$ A mentális állapotok feltételezett jelenléte ebben a komputer által létrehozott világban a szereplôknek tudatos múveleteket, kognitív folyamatokat és affektív állapotokat tulajdonít, azaz mentalizációs tevékenységet mozgósít.

\section{Elhagyás-megérkezés dimenzió}

A tudatos ottlét és a tudatos máshollét dinamikus tudatállapot-változásokat feltételez, melyek állomásai a virtuális valóságba való megérkezés (arrival) és a fizikailag valós környezetbôl történô eltávozás (departure) élménye. Szeretném kiemelni, hogy ez esetben az eltávozás nem elhagyást jelent, hanem magában rejti a fizikailag átmenetileg mellőzött, de a visszatérés lehetôségét megtartó helyre utaló megnevezést. Nem elhagyásról, végérvényes szakításról (detachment), hanem eltávozásról van tehát szó. Nyitva marad az út a visszatérés (returning) irányába. Az akció során a személy tudomásul veszi a megérkezés és az eltávozás tényét, és ugyanakkor érzéseire reflektálva számol ezek következményeivel és ideiglenességével is. Az ismert, esetleg biztonságos, támogató vagy ellenkezôleg, taszító környezet a motiváció jellegétôl függôen új, vonzóbb világok iránti vágyakozást kelt. Ugyanakkor új érzelmi köteléket vagy elzárkózási lehetôséget is magába foglal. A VR-ben való kiteljesedés és az elzárkózás lehetôsége egyaránt nyitott. A valóság és a virtuális valóság közötti ide-oda táncolás érzelmi tekintetben is lemásolja a bizonytalan helyzetekre vonatkozó tárgykapcsolati reprezentáció

Ennek a tárgyszerû elemekbôl felépülố (komputer, HMD) környezetnek az értelmezése a kognitív fejlôdésének megfelelốn zajlik. A tárgyaknak, állapotoknak gondolatot, terveket tulajdonító animizmus, valamint a humán szocializációt meghatározó mentalizáció egyaránt részt vesz a virtuális környezet és a szereplôk tevékenységének értelmezésében. 
sajátosságait. A VR-hez való viszony és a felhasználás módja gyermekkori érzelmi és kognitív fejlődés nyomdokain halad. A VR mentális reprezentációja követi a szelfszervezôdés fokozatait. Következésképpen a VR gyakori alkalmazása a mentális fejlôdés bármely idôszakában jelentôs mértékben befolyásolja a tárgykapcsolatok és a mentális fejlődés kritikus idôszakainak megjelenését, valamint a fejlôdési krízisek kimenetelét (Riva, Montovani és Bouchard, 2014).

\section{Átmeneti jelenlét}

Kognitív szempontból a legnagyobb kérdés az átmeneti jelenlét tartósítása vagy az ideiglenes jelenlét tartós feladása. A realitáskontroll a tervezô, kivitelezó és a tevékenység eredményét visszajelentô mentális funkciók egységét jelenti. Ennek a sérülése hibás gyakorlatok kialakulásához vezet. Hasonló jelenségek figyelhetôk meg a prefrontális kortex léziója, zavart tudatállapotok, disszociatív munkamódok, deperszonalizáció, testi funkciók kóros megfigyelése, impulzivitás, indítékszegénység, depresszió és szorongásos zavarok esetében (Wiederhold és Wiederhold, 2008).

\section{Személyiségdiszpozíciók}

A VR iránti érzékenység és annak mélysége a hangulati állapottól, a tudatállapottól, a motivációktól függ, továbbá személyiségdiszpozíciókon is múlik. A korai vizsgálatok szerint (Kaber, Draper és Usher, 2002; Tellegen, 1982) a szuggesztibilitás, a zavaró események kizárására való képesség, a nappali ábrándozásra, az abszorpcióra való hajlam, az olvasmányi, filmnézési élményekbe való teljes belemerülés és a hipnózis iránti fogékonyság esetén számíthatunk fokozott jelenlétélményekre a VR-ben. Feltételezések szerint (Lauria, 1997; Lombard és Ditton, 1997) a mindfulness gyakorlatokban jeleskedôk, valamint a mezôfüggetlen szemlélettel rendelkezô személyek (Hecht és Reiner, 2007) részérôl a VR-ben a testi ottlétélmény igen karakteres megjelenési formáira számíthatunk.

\section{Az affordanciák ${ }^{10}$ szerepe}

A mindennapok cselekvési lehetôségeinek felismerésekor az affordanciák közül választva indul el a kontrollált és a nem kontrollált sémákban tárolt, a szokáserôsség alapján rangsorolt válasz. A készen álló, megnyilatkozási alkalomra váró lehetôségek

10 Gibson (1966) affordanciafogalma szerint nem különálló ingereket, hanem sémákba rendezôdô ingermintákat érzékelünk. Az ingerminta és a válasz kapcsolatát rögzítô sémák minden olyan alkalommal aktiválódnak, amikor ezek a kivitelezési lehetôségeket elốrevetítố inger-válasz feltételek a percepcióban adottak. Például a kalapács látványa mozgósítja a marokszorítást, a kalapács kézbevételekor aktiválódó hajlító és feszítô karizmok megfelelô mintázatát a munkafolyamat megkezdéséhez. Tehát dolgozunk már a szerszámmal, mielôtt azt a valóságban kézbe vennénk. Ezek a kész inger-válasz mozgásegységek más környezetre és ingerszegény feltételekre, többek között a VR-re is áttranszponálhatók. 
közül a képhez, eszközökhöz, szükségletkielégítéshez illeszkedố cselekvés vagy inger azonosítása zajlik, amit az esetek többségében figyelemszúró, az akció indítására vagy gátlására vonatkozó döntési folyamat zár le. Ezek az affordanciák a VR-ben is múködnek, kiváltják a hatásukat, különösen akkor, ha a személyek megfelelố képzelốerôvel és tettrekészséggel, azaz motivált állapotban vesznek részt a VR-ben történô eseményekben vagy azok értelmezésében (Gross, Stanney és Cohn, 2005; Shin, 2017).

\section{Próteusz-hatás ${ }^{11}$ (Proteus effect)}

Az affordanciák által kínált válaszlehetôségek áttételesen a másoknak tulajdonított képességek és karaktersajátosságok kongruenciája formájában is megjelennek. A VR-ben zajló diádikus kommunikáció vizsgálata során a vizsgált személy saját avatárja (megtestesítôje) képében vett részt egy személyes beszélgetésben. Az avatár külsejét és testalkatát különbözố kondíciók során módosították. Az avatár egyik esetben magas, megnyerố külsejû, más esetben alacsony és kevésbé vonzó kinézetben jelent meg. A két helyzetben lezajlott beszélgetés formai és tartalmi elemzése alapján megállapították, hogy a magas, vonzó kinézetủ alakban megjelenô avatár esetén az avatárt irányító szereplő az alacsonyabb és kedvezôtlenebb kinézetú alak alkalmazásához mérten magabiztosabb, közvetlenebb és hatékonyabb kommunikátornak bizonyult. A szereplô nemcsak az avatárral, de a küllemébôl származó vélt elốnyökkel is azonosult, a szereplô viselkedése tudattalanul illeszkedett az általa megszemélyesített avatárnak a szociális sztereotípiák alapján tulajdonított lehetôségeihez (Yee és Bailenson, 2007). A viselkedésilleszkedés (Chen és Bargh, 1997), az önészlelés módosítása (Bem, 1972) és az egyéniség jelentôségének megszúnése, az anonimitás keresése, a csoport-, pártvagy szurkolói csoportérdek mögötti rejtôzködés (deindividuation) (Postmes, Spears és Lea, 1998; Yee, Bailenson és Ducheneaut, 2009) jelentôs szerepet játszik ennek a hatásnak a kialakulásában. Az avatárral való azonosulás mértéke természetesen befolyásolja a hatás mértékét. A szereplőnek az avatárral vagy a virtuális partnerrel való identifikációja viszonylag egyszerú eszközök segítségével elôsegíthetô. A multimodális (auditív, taktilis, vizuális, proprioceptív) ingerlés szinkronizálása elôsegíti az azonosulás kognitív és affektív oldalának elmélyülését. ${ }^{12}$ A Próteusz-hatás jól mutatja a VR alkalmazásának lehetôségeit a testképzavarok, szorongásos és más pszichopatológiai állapotok kezelésében. Az effektus, különösen a negatív, félelemkeltô, bosszúálló fi-

11 Próteusz egy mitológiai szereplô, aki a legkülönbözôbb alakokat (magas, alacsony, vékony, kövér, gyenge, erôs, hôsies, bátortalan) és formákat (tûz, víz, szobor, fa, épület) képes magára ölteni. Igazi alakváltó, de mindig megốrzi a jövôbelátó képességét. Alakja rámutat egy ember sokféleségére. Ô az, aki közvetíteni képes az egymásra ható megjelenési formák között. Azonban sokszor maga sem tudja, hol és mikor, milyen formát vesz fel. Weöres Sándor Átváltozások ciklusában Próteuszra emlékezve kifejti: nem csak az ember olvassa a verset, a vers is olvassa az embert. A különbözô megjelenési forma az ember „testi-lelki önmagát emeli egyre értékesebbé”. A költôi példa talán szükségtelen, de a magyar olvasó számára ez a megfogalmazás élményszerúen mutatja meg a Proteus effect eredeti tartalmát.

12 Részletesebben lásd Petkova, Bjornsdotter, Gentile és Ehrsson (2011) vizsgálataiban és Kállai, Szolcsányi és Hegedüs (2013) összefoglalójában. 
gurákkal való rejtett azonosulás következtében a személyiségfejlôdésben, kriminális cselekedetek motivációjában és lezajlásában is megjelenik. ${ }^{13}$

A VR érzékelése és az ottlét élményével kísért tevékenység következményeinek elemzése a képességfejlesztés és a személyiség fejlôdése szempontjából lényeges pszichológiai mechanizmusok tárháza. Hasonlóan a filmek nézésekor, olvasmányokba való belemerüléskor, a megváltozott tudatállapotok során szerzett tapasztalatok értékelésekor alkalmazott lélektani múveletekhez, megjelenik a modellképződés, identitásalakulás, az önbizalom erôsödése, ugyanakkor a programkínálat és a virtuális térbe bevont szereplố személyiségének hátrányos hatásai is tetten érhetôk. A fentiekben felsoroltak ízelítốt jelentenek a VR-ben zajló pszichológiai mechanizmusok sokrétû vizsgálatához. Vannak azonban olyan specifikumok, amelyek megbízható azonosítása még várat magára. A VR és az ember interakciója nemcsak az ipari felhasználásban, a munkaergonómia fejlôdésében (Hercegfi és Izsó, 2007), a speciális munkakövetelmények által támasztott szenzomotoros fejlesztésekben, új játékok hatásmechanizmusának vizsgálatában fontos, de szerepe fokozatosan növekszik az orvostudomány (Riva, 2008), az oktatás (Sala, 2016) és a kutatási tevékenység (Bohil, Alicea és Biocca, 2011) területén is. A VR hosszabb távú fejlődésével kapcsolatosan gyakran beszélnek egy második világ (second world) fokozatos megszületésérôl, melynek törvényei meghaladják a fizikai törvényeket, és inkább az emberi fantázia kiteljesedését, a mitikus gondolkodás megtestesülését, a fantáziavilág tárgyiasulását és a más személyek által felvetett magyarázatok, valóságábrázolások elfogadására való ösztönzés szemléletes és hatékony eszközét látják benne. Tudomásul kell vennünk, hogy egy gyermek és egy felnôttt gondolkodásmódjának és realitásérzékének a fejlôdése, a valóság ismerete családi hagyományokon, tudományos, pedagógiai, múvészi és politikai valóságábrázolási formákon múlik. A VR ebból a szempontból egy újabb ábrázolásforma. A többihez mérten a VR jelentôsen különbözik az alternatív lehetôségek felhasználási módjában. Lényegében a technikai apparátus ideiglenesen lezárja az alternatív valóságértelmezések egyéb módjainak felhasználását, és mellékessé teszi a VR-ben zajló interakciók következményeit. A valóságértelmezésben bizonyos feltételek mellett könnyen egyeduralkodóvá válik. Ezeket a hatásokat elôre sejtjük, de a következmények pontos felmérésével még adós a tudomány és a hatékony gyakorlat kialakítására törekvô kritikus fejlesztői közgondolkodás.

\section{MÉRÉSI LEHETŐSÉGEK}

A VR-ben való jelenlét mérésére számos, de sok esetben validitás szempontjából még ellenôrzésre szoruló eszköz kínálkozik. Egyszerûségük miatt az offline kérdôíves és online vizuális analóg értékelôskálák a legnépszerúbbek. Az online vizuális analóg skálák az aktuális jelenlétélmény intenzitására kérdeznek rá. Globális élménykvalitást mérnek, így részletesebb analízisre, az ottlét különbözó elemeinek tagolására nem adnak lehetôséget. A válasz módja nem zavarja meg jelentôsebben a válaszadó ottlét-

13 Ezekrôl részletesebben a késôbbiekben a VR-alkalmazások egy másik fejezetében fogunk majd beszámolni. 
élményét, a kiértékelés módja nem okoz komplikációkat. Az offline kérdőíves tételek alapján már differenciáltabb, de kevésbé meggyôzố válaszok nyerhetôk. Az egyik legnépszerúbb, de folyamatosan módosított kérdő́ives eljárás a Witmer és Singer (1998) által kidolgozott jelenlét kérdőív, mely a technikai feltételek oldaláról a VR motoros interakciós lehetôségeit, a multimodális koherenciára vonatkozó élményt, valamint a jelenlétre vonatkozó, zavaró hatásoktól mentes figyelem-összpontosítást és a valósághúség-élmény mértékét méri fel. ${ }^{14}$ A kérdôív szétválasztható két, belemerülésre és jelenlétre vonatkozó kérdôívre is. Az offline felvett válaszok azonban nem veszik figyelembe azt a tényt, hogy a VR-ben végzett feladatmegoldás közben a figyelem a virtuális és a valós környezet között bizonyos mértékig oszcillál (Slater és Steed, 2000).

A pszichofiziológiai vizsgálatok eredményei nagyrészt követik a valós körülmények között megjelenô pszichofiziológiai reakciómintákat. A VR-ben a veszélyes és veszélytelen helyiségbe való belépés vagy magas helyen tartózkodás jelentôs, a jelenlétélménynyel is kapcsolatban álló szívritmus- és bőrvezetôképesség-változásokat eredményez (Meehan, Insko, Whitton és Brooks, 2002). A virtuális környezetben átélt veszélyérzet, a direkt fizikai fenyegetettség emeli a szívritmust, növeli a bőr elektromos vezetôképességét, fokozza a légvételek számát, és növeli az EEG bétaaktivitásának mértékét, továbbá fokozott aktivitás mutatkozik a multimodális inkoherenciákra érzékeny agyi területeken, elsôsorban az anterior cinguláris kortexben (Peterson, Furuichi és Ferris, 2018; Strickland és Chartier, 1997). A szívritmus és a bőr-vezetôképesség a szokott stresszmintázatot mutatja az azt követô percekben, hogy a személynek el kell hagynia a VR-t, és off pozícióba kerül (Slater, Brogni és Steed, 2003). A jelenlétélmény intenzitása összefügg tehát a fiziológiai válaszreakciók intenzitásával, de nem ismert még pontosan, hogy más technikai feltételek vagy pszichológiai prediszpozíciók milyen szerepet játszanak az intenzív pszichofiziológiai válaszok megjelenésében. Jelen ismereteink szerint a hipnózis iránti befogadó attitûdnek és az abszorpciós képességnek fontos szerepe van a jelenlétélmény és a VR-re adott fiziológiai reakciók megjelenésében (Macedonio, Parsons, Digiuseppe, Wiederhold és Rizzo, 2007).

A viselkedéses teljesítménymutatók online szenzomotoros mutatói tekintetében változó a kép. Reflexes mozgások és akciók esetén a vizuális jelenet által kiváltott testtartásváltozás mértéke, a célirányos lokomóciólassulás, a veszélyre megjelenô elkerülô reakció nagysága szoros összefüggésben van az offline mért ottlétélmény intenzitásával (Prothero, Parker, Furness és Wells, 1995). Összetettebb és mentálisan kontrollálhatóbb viselkedés esetén azonban számos bizonytalanság vetôdik fel. A VR-ben fizikai veszélyt imitáló, vizuálisan reális helyzettel való szembesülés a kijelölt cél megközelítésekor lokomóciólassulást eredményez, de az elemzôknek nincs információjuk a mechanizmusról, a lassulás forrásáról. A motoros teljesítményt ugyanis számos tényezô, a figyelem iránya, a koncentráció mértéke, a disztraktorok hatékony kizárása, a szemmozgások adaptivitása és számos egyéb funkció mozgósítása befolyásolja, melyek a mindennapi viselkedés irányításában egésszé szervezôdve vesznek részt. Nincs részletes információ arról, hogy a testtartás esetleges megváltozása szerepet játszik-e a mozgást lassító múveletek kivitelezésében. Tehát keveset tudunk a viselkedés realitásáról (behavioral realism), csak feltételezzük, hogy a végeredmény kialakulásában a

14 A kérdôíves mérési lehetôségek részletes ismertetését lásd Hupuczi (2014) munkájában. 
kognitív és viszcerális, proprioceptív folyamatok egységes mintázatban jelennek meg a VR-ben végzett feladatok kivitelezésekor. Következésképpen sokszor nem vagyunk tisztában azzal, mi az, amit a személy a VR-ben valójában egy feladat megoldásakor gyakorol. Ezek a bizonytalanságok a modern vizsgálati körülmények biztosításával csökkenthetôk, de az ipari, klinikai és oktatásügyi alkalmazások miatt nem hagyhatjuk figyelmen kívül ôket.

\section{ALKALMAZÁSOK}

A VR alkalmazása során az oktatásban, gyógyító tevékenységben, és tegyük hozzá, a szórakoztatóipari felhasználáskor szerzett tapasztalatok megítélésében kulcskérdés az alkalmazók testi-lelki részvételének mértéke. A modern eszközök nemcsak egyszemélyes, de társas interakciókban való részvételre is megteremtik a lehetôséget. Az alkalmazó elkötelezettségétôl függóen az identitását is próbára teszi a problémák megoldása során. Hangot kell adnia, képet, érzéseket, vágyakat kell mutatnia egyrészt saját maga, másrészt a VR-ben megjelenô egyéb szereplők számára. A fizikai realitástól függetlenül lehetôség van a különbözó formák, karakterek megjelenítésére, értékeket közvetítő, megfigyelôi vagy résztvevői pozíció felvételére. Átmeneti énállapotok is felvehetôk (úgynevezett próbajátékok), lehetôség van a személyes én határainak felfüggesztésére, ami kreatív vagy destruktív célokat egyaránt szolgálhat. A saját én képviseletének módja tehát sokszínú, de minél közelebb áll a résztvevô az eredeti személyiségéhez, önmagáról ôrzött képéhez, tanulási és terápiás folyamatban való részvétel esetén annál nagyobb személyes profitot érhet el. Az öndefiníció lényege a személyes megjelenés, érzések, vágyak, testi funkciók, célok átélése és kifejezése (embodiment), melyben a testséma és a testkép egységet képez, melynek során a személy olyan személynek érzi és gondolja magát, aki képes átérezni, hogy teste és lélektani megnyilvánulásai adott idóben és adott térben ugyanott és ugyanakkor vannak jelen (sense of self-location). Aktív szereplöje a környezetének, és személyes részvételén keresztül befolyásolni akarja a környezetében zajló fizikai és szociális eseményeket (sense of agency). Továbbá személyes viszonyban van a testével, érzelmeivel, gondolataival, melyeket sajátjainak tulajdonít (sense of ownership) (De Vignemont, 2011; Kilteni, Groten és Slater, 2012).

\section{Oktatásügyben}

Az oktatásügy szereplôi kemény versenyt folytatnak a technikai és humán erôforrások hatékonyabb alkalmazása érdekében. A hagyományosan a tanulás és tanítás alapjait meghatározó Bandura-féle (1986) szociális tanulási modell szerint a tanár által képviselt kompetens, sikeres, példamutató, a tananyagot elôzetesen rendszerszintú ismeretekbe ágyazó és azt szemléletesen prezentáló, ezért követendô modellt nyújtó pedagógus katedrája alternatív ismeretszerzố stratégiákkal találja szemben magát. Az internet és a mobilapplikációkon keresztül folyamatosan elérhetô friss információk vetekednek a tanár naprakészségével, ugyanakkor a figyelem fenntartása, a tartós kon- 
cepciókra épülô ismeretek elsajátítása és megôrzése tekintetében személyes alternatívát képviselnek a hallgatók számára. Az internet és a VR világában a hallgatók jelentôs csoportja számára a saját élményekre összpontosuló, ismereteket letöltô és továbbító aktivitásuk árnyékában sokszor nosztalgikus erőfeszítésnek tűnik a pedagógus munkája. Az új kulturális fejlôdési stratégiák is indokolják a jelenlegi oktatási rendszer és a bôvülô technikai alkalmazások intenzívebb együttmúködését, a tanítók és a tanulók kölcsönös céljainak egyeztetését. A tanítók és tanulók közötti kompetitív viszony hátráltatja a hatékony ismeretelsajátítási rendszer fejlôdését. A virtuális valóságok ebben a küzdelemben közvetítô alternatívát jelentenek az oktatási rendszer fejlôdéséhez.

A VR a tanulási eredményesség és a tanítási hatékonyság növelésének repertoárt bôvítô eszköze, melynek során a kialakított VE kívánalmait kielégítendô, a tanár és a diákok társas és egyéni környezetét idôlegesen virtuális színtérbe helyezik át (transformed social interaction, TSI). A tananyag a virtuálisan megszemélyesített tanár vagy a virtuálisan jelen lévô diákok egyéni vagy csoportos kezdeményezése alapján válik az érdeklôdôk számára hozzáférhetôvé (Bailenson, Yee, Blaschovich, Beall, Lundblad és Jin, 2008). Közbevetôleg meg kell itt jegyeznünk, hogy a korszerú tanítási környezet, a tanulók által hozott, kiválasztott személyes történetek, személyes kutatási eredmények alapján feltárt információk bekerülnek a tanterem közös tudást szimbolizáló erôterébe (embodied teaching). A személyes erőfeszítésre és a csoporttagok közötti kollaborációra épító interakciók eredményeként megszületett döntések és feldolgozott tananyag a VE-ben való motivált részvétel legfontosabb közösségteremtô hajtóereje. A hagyományos videóhoz, tévéhez és képkivetítô szemléltetô eljárásokhoz képest a VE szintetikus szenzoros környezete vizuális realitást kelt, mely megfelelô programozási eljárások segítségével a tanulási és tanítási stratégiák, a szemléltetés és a sok esetben életszerú feltételek között végzett problémamegoldási gyakorlatok számára több lehetôséget kínál. A lehetôségek közül kiemelkedik a VE-ben megjelenô, a tanulók által különbözô médiákból jól ismert, esetleg hasonló életkorú szereplő alkalmazása, aki a tanulócsoportnak vagy személynek szólóan, kompetenciájának megfelelően, közvetlen személyes élményei alapján mutatja be a tudását, adja fel a feladatokat, és rámutat a megoldási krízisek esetén követendô sikeres megoldásokra. Virtuális tutorként szabályozni tudja a megoldás helyes menetét. Következésképpen a katedráról elhangzó elraktározás-központú tanulás helyett a megfelelően felépített VE inkább a konstrukciós elvekre épített tanulási formák számára kedvezô. Kiemelendô ugyanakkor, hogy a VE-ben szerzett tudást a nyelvi kifejezôképesség fejlesztése érdekében a történtek elbeszélésével meg kell osztani másokkal, osztálytársakkal, esetleg független személyekkel (Cassell, 2004). A virtuális tanulótárs az osztályteremtôl távol, az egyéni felkészülés során nyújt a szülôk mellett kiegészítô fejlesztési lehetôséget. A társas tanulás nemcsak ösztönzóbb, de a tényanyag megszerzése szempontjából is eredményesebb, és jelentôs szerepe lehet a tanulmányaikban lemaradt személyek felzárkóztatásában (Kim és Baylor, 2006). A vizualizációs lehetôségek bôvülése jelentôsen növeli a tananyag feldolgozását, mélységét és eredményességét. A háromdimenziós megjelenítés, a jelenetek, objektumok, fizikai történések, kémiai szerkezetek szemléltetése, a tárgyak, helyszínek egymástól való távolságának megítélése, a madártávlatból és az adott helyszínen felvett jelenetek összehasonlító elemzése tág teret kínál a megértés és a többszörös emlékezeti rendszerbe való elraktározás számára (Psotka, 1996). 
Készségfejlesztéskor a taktilis és finommotoros mozgások több nézôpontból történô vizuális megjelenítése a komplex mozgások megértésének jó fejlesztési lehetôségeit kínálja (Palter és Grantcharov, 2010).

\section{Egészségügyi, pszichoterápiás ellátásban}

Az egészségügyi ellátás gazdag irodalmából emeljünk ki néhány témát, melyek bizonyítják a VR növekvô szerepét az eredményesebb pszichoterápiás ellátásban és a rehabilitációban. A pszichoterápiában a VR alkalmazásának - elsôsorban a kognitív és viselkedésterápiákhoz kötődôen - hosszú történelme van. A folyamatosan gazdagodó eljárások sorából ezen a helyen csak néhány példát említünk azok közül, melyek beválását az elmúlt évek terápiás praxisa már megfelelően bizonyította. A szorongásos zavarok terápiájában már a VE kifejlesztésének korai idôszakában bevezették a VR által támogatott deszenzitizációs és elárasztásos gyakorlatokat, melyek szép eredménnyel jártak. A szorongásos zavaroktól szenvedô személyek személyiségének egyes sajátosságai, a dependencia, érzelmi labilitás és a gyakran ezzel együtt járó énhatár-bizonytalanságok, a fokozott abszorpciós képesség és a testi tudatosság támogatta ezen eljárások sikeres alkalmazását. A személyiségzavarok esetében tapasztalható alacsonyabb együttmúködés és általában a hosszabb idejû személyiségfejlesztô kapcsolatra építô terápiás stratégia miatt a VR kevésbé jött szóba. A disztrakciós tendenciák, a fokális figyelem, a betegségtudat hiánya, a hallucinációk, a realitáskontroll és az énhatárok súlyos deficitje miatt pedig a szkizofrén betegek esetében kifejezetten kontraindikált volt a VR-eljárások bevetése. Az elmúlt tíz évben a kognitív terápiás technikák intenzív fejlôdése, a dialektikus megközelítés (Perczel-Forintos, 2011), a sémák átalakítására összpontosító beavatkozások (Unoka, 2010) lehetôvé tették ezen a területen is a VR-ral asszisztált hatékony ellátást. ${ }^{15}$ Amennyiben figyelembe vesszük azt a tényt, hogy a szkizofréniában az éntudat, testtudat, identitásvesztés a patológia központi eleme, mégis felvetôdik a kérdés, hogy a VR, amely a különbözô valóság- és ezzel énállapotok közötti átváltásra épül, miért ne szolgálhatna egy új utat e zavarok megszüntetésében vagy korrekciójában. Napjainkban a VR-t hatékonyan alkalmazták hallucinációk, téveszmék csillapítására és szkizofréniás betegek rehabilitációjában (Freeman, 2008; Freeman és mtsai, 2016). A magasságtól, utazástól, állatoktól, nyilvános szerepléstôl való rettegés jól modellálható VR-körülmények között. A szorongásos betegségek ellátásában hazai hagyományai is vannak a VR-közbeiktatásban végzett kezeléseknek (Simon, Lányi és Simon, 2005). Az ingerelárasztási technikák alkalmazása ilyen feltételek mellett kíméletes, és jó eredményt hoz. A poszttraumás stresszbetegség tüneteinek enyhítésében és a krónikus fájdalom deszenzitizálásában is meghatározó szerepet töltenek be (Botella, Palacios, Baños, Quero és Breton-Lopez, 2008; Wiederhold és Wiederhold, 2008). A VR-be ágyazott tesztek és gyakorlatok validitásának és hatékonyságának ellenôrzését követően (Díaz-Orueta, Garcia-López, Crespo-Eguílaz, Sánchez-Carpintero, Climent és Narbona, 2014) a gyermek- és felnôttoktatásban, valamint a neurorehabilitációs el-

15 Hazánkban a VR alkalmazásának inkább a szorongásos zavarok kezelésében van bizonyos hagyománya. 
látásban az elkövetkezó években növekedni fog a virtuális környezet szerepe. Jelenleg a gyakorlati eredmények visszajelentése alapján több, folyamatosan bôvíthetố egészségfejlesztố VR-programkörnyezet kialakítása zajlik. A fejlesztések fókuszában a rehabilitáció, a pszichiátriai betegségek és az egészségfejlesztô, attitúdformáló, képességfelmérô és -fejlesztô eszköztár kidolgozása áll. Ezek közül a legsikeresebb a Nesplora Neuroscience Support Systems (cordis.europa.eu/project/rcn/207033) kutatási és innovációs program.

\section{ÖSSZEFOGLALÁS ÉS PERSPEKTÍVÁK}

A komputer által létrehozott VR-ben a virtuális valóságok más típusaihoz képest eltérố a valóság reprezentációjának oszcillációja. Az elmerülést biztosító technikai rendszer, a gondosan kidolgozott és programozott multimodális ingerminták és a valós környezettel való közvetlen kapcsolatot lezáró HMD alkalmazása, a válaszlehetôségek kontrollja a személy perceptuális terébốl lényegében kiszorítja a fizikai realitás egy jelentôs részét. Egy remote, ${ }^{16}$ azaz közvetett valóságot hoz létre, melyből a személy a realitás ismételt ellenôrzése érdekében kilép, majd újra visszalép. A VR használata közben a résztvevốk gyakran számolnak be a jól ismert szédülés jelenségérôl. Természetszerúen vetôdik fel a kérdés, hogyan érinti ez a jelentôs kognitív reprezentációváltás azon személyek kognitív képességeit, akik esetén az oszcilláció másokhoz mérve gyakran fordul elố ${ }^{17}$ A kognitív fejlốdést és a klinikai alkalmazást egyaránt alapvetően érintô, a virtuális valóságban zajló reprezentációváltás különbségeirôl mind ez idáig keveset tudunk. Az ezek kimenetelével kapcsolatos bizonytalanságok megnehezítik az oktatásban és a pszichoterápiákban alkalmazott virtuális környezetben zajló kognitív és affektív folyamatok közötti integráció megértését, lényegében a fizikai valóságba átvihetố tapasztalatok realitásának az elfogadását.

\section{KÖSZÖNETNYILVÁNÍTÁS}

Köszönettel tartozom tanítványaim és kollégáim értékes kritikai megjegyzéseiért, amelyek tárgyszerúbbé tették az összefoglalót. A tanulmány elkészítését az NKFI-120334 kutatási pályázat támogatta. mény, helyzet, emlékkép elôhívására, a hosszú idejú emlékezeti tár mozgósítására vonatkozik.

17

A vesztibiláris és a vizuális rendszer hasonló instabilitásáról diszlexiás és pániktól, agorafóbiás tünetektổl szenvedô személyek esetén számoltak be. Klinikai relevanciái is lehetnek a VR-ben megmutatkozó distressznek. Lásd részletesebben Jacob, Furman, Clark és Durrant (1992), valamint Kállai (2015), Kállai és munkatársai (2013) munkáiban. 


\section{IRODALOM}

Bailenson, J. N., Yee, N., Blaschovich, J., Beall, A. C., Lundblad, N., \& Jin, M. (2008). The use of immersive virtual reality in the learning sciences: Digital transformations of teachers, students and social context. The Journal of the Learning Sciences, 17(1), 102-141.

Bandura, A. (1986). Social foundations of thought and action: A social cognitive theory. Prentice-Hall, Inc.

Baron-Cohen, S. (2001). Theory of mind in normal development and autism. Prisme, 34, 174-183.

Bem, D. J. (1972). Self-perception theory. Advances of Experimental Social Psychology, 6(1), 1-62.

Bohil, C., Alicea, B., \& Biocca, F. (2011). Virtual reality in neuroscience research and therapy. Nature Reviews Neuroscience, 12(12), 752-762.

Botella, C., Palacios, A. G., Baños, R., Quero, R., \& Breton-Lopez, J. (2008). Virtual reality in the treatment of pain. Journal of CyberTherapy and Rehabilitation, 1(1), 93-100.

Burdea, G. C., \& Coiffet, P. (2003). Virtual Reality Technology. Wiley-IEEE Press, New York.

Cassell, J. (2004). Towards a model of technology and literacy dependent: story listening system. Journal of Applied Developmental Psychology, 25(1), 75-105.

Chen, M., \& Bargh, J. A. (1997). Nonconscious behavioral confirmation processes: The self- fulfilling consequences of automatic stereotype activation. Journal of Experimental Social Psychology, 33(5), 541-560.

Csibra, G., \& Gergely, Gy. (2013). Teleological understanding of actions. In M. R. Banaji, \& S. A. Gelman (Eds), Navigating the Social World: What Infants, Children, and Other Species Can Teach Us (pp. 38-43). Oxford: Oxford University Press.

Deroy, O., Faivre, N., Lunghi, C., Spence, C., Aller, M., \& Noppeney, U. (2016). The Complex Interplay Between Multisensory Integration and Perceptual Awareness. Multisensory Research, 29(6-7), 585-606. DOI: 10.1163/22134808-00002529

De Vignemont, F. (2011). Embodiment, ownership and disownership. Consciousness and Cognition, 20(1), 82-93. DOI: 10.1016/j.concog.2010.09.004

Díaz-Orueta, U., Garcia-López, C., Crespo-Eguílaz, N., Sánchez-Carpintero, R., Climent, G., \& Narbona, J. (2014). AULA virtual reality test as an attention measure: Convergent validity with Conners' Continuous Performance Test. Child Neuropsychology, 20(3), 328-342. DOI: 10.1080/09297049.2013.792332

Ellis, S. R. (1991). Nature and origin of virtual environment: A bibliographic essay. Computing System in Engineering, 2(4), 321-347.

Freeman, D. (2008). Studying and treating schizophrenia using virtual reality: A new paradigm. Schizophrenia Bulletin, 34(4), 605-610.

Freeman, D., Bradley, J., Antley, A., Bourke, E., DeWeever, N., Evans, N., et al. (2016). Virtual reality in the treatment of persecutory delusion: randomized experimental study testing how to reduce delusional conviction. The British Journal of Psychiatry, 209(1), 62-67.

Gentile, G., Petkova, V. I. \& Ehrsson, H. H. (2011). Integration of visual and tactile signals from the hand in the human brain: an FMRI study. Journal of Neurophysiology, 10(2), 910-922. DOI: 10.1152/jn.00840.2010

Gibson, J. J. (1966). The Senses Considered as Perceptual Systems. London: Allen and Unwin.

Gross, D., Stanney, K., \& Cohn, L. (2005). Evoking affordances in virtual environments via sensori-stimuli substitution. Presence: Teleoperators and Virtual Environments, 14(4), 482-491.

Hecht, D., \& Reiner, M. (2007). Field dependency and the sense of object - presence in haptic virtual environment. CyberPsychology and Behavior, 10(2), 243-251.

Hercegfi, K., \& Izsó, L. (2007). Ergonómia. Budapest: Typotex Kiadó. 
Hupuczi E., (2014). A Spatial Presence elmélet strukturális egyenlet modellezése: Operacionalizálhatóság és felhasználói faktorok szerepe a modellben. Nem közölt kézirat. Pécs: PTE BTK Pszichológiai Intézet.

Ijsselsteijn, W., \& Riva, A, G. (2003). Being There: The experience of presence in mediated environments. In G. Riva, F. Davide, \& W. A. IJsselsteijn (Eds), Being There: Concepts, effects and measurement of user presence in synthetic environments (pp. 3-16). Amsterdam, The Netherlands: Ios Press.

Insko, B. E. (2003). Measuring presence: Subjective, behavioral, and physiological methods. In G. Riva, F. Davide, \& W. A. IJsselsteijn (Eds), Being there: Concept, effects and measurement of user presence in synthetic environments (pp. 413-434). Amsterdam, The Netherlands: Los Press.

Jacob, R. G., Furman, J. M., Clark, D. B., \& Durrant, J. D. (1992). Vestibular symptoms, panic, and phobia: Overlap and possible relationships. Annals of Clinical Psychiatry, 4(3), 163-174.

Kaber, D., Draper, J., \& Usher, J. (2002). Influence of individual differences in VR application design for individual and collaborative immersive virtual environment. In K. Stanney (Ed.), Virtual reality handbook (pp. 379-402). New York: Lawrence Erlbaum.

Kállai, J., Szolcsányi, T., \& Hegedús, G. (2013). Múkéz illúzió. „Hozzám tartozik, de nem az enyém." Magyar Pszichológiai Szemle, 68(3), 457-474.

Kállai, J., (2015). A társas kapcsolatok neuropszichológiája. Budapest: Medicina Kiadó.

Kilteni, K., Groten, R., \& Slater, M. (2012). The sense of embodiment in virtual reality. Presence, 21(4), 373-387.

Kim, Y., \& Baylor, A. L. (2006). A social-cognitive framework for pedagogical agent as learning companions. Educational Technology Research and Development, 54(6), 569-590.

Lauria, R., (1997). Virtual reality: An empirical meta physical testbed. Journal of Computer-Mediated Communication, 3(2). DOI: 10.1111/j.1083-6101.1997.tb00071.x

Lawson, B. D. (2014). Motion sickness symptomatology and origins. In K. S. Kelly, \& K. M. Stanney (Eds), Handbook of Virtual Environment: Design, implementation, and applications, 2nd ed. (pp. 532-587). Boca Raton, FL: CRC Press.

Lombard, M., \& Ditton, T. (1997). At the heart of all: The concept of presence. Journal of Computer-Mediated Communication, 3(2).

Macedonio, M. F., Parsons, T. D., Digiuseppe, R. A., Wiederhold, B. A., \& Rizzo, A. A. (2007). Immersiveness and Physiological Arousal within Panoramic Video-Based Virtual Reality. CyberPsychology and Behavior, 10(4), 508-515.

Meehan, M., Insko, B., Whitton, B., \& Brooks, F. P. (2002). Physiological measures of presence in stressful virtual environments. ACM Transactions on Graphics. Proceedings of ACM SIGGRAPH, 21(3), 645-653.

O'Keefe, J., \& Nadel, L. (1978). The hippocampus as a cognitive map. Oxford: Oxford University Press.

Palter, V. N., \& Grantcharov, T. P. (2010). Virtual reality in surgical skills training. Surgical Clinics of North America, 90(3), 605-617. DOI: 10.1016/j.suc.2010.02.005

Perczel-Forintos, D. (2011). A kognitív terápia fénykora: a második és harmadik hullám. Magyar Pszichológiai Szemle, 66(1), 11-29. DOI: 10.1556/MPSzle.66.2011.1.2

Peterson, S. M., Furuchi, E., \& Ferris, D. P. (2018). Effects of virtual reality high heights exposure during beam-walking on physiological stress and cognitive loading. PlosOne, July 6. DOI: 10.1371/journal.pone.0200306

Petkova, V. I., Bjornsdotter, M., Gentile, G., \& Ehrsson, H. H. (2011). From Part- to Whole-Body Ownership in the Multisensory Brain. Current Biology, 21(13), 1118-1122. DOI: 10.1016/j. cub.2011.05.022

Piaget, J. (2002) [orig. pub. 1928]. Grammar and Logic. Judgement and Reasoning in the Child. International Library of Psychology. Developmental Psychology. Vol. 23. London: Routledge. 
Postmes, T., Spears, R., \& Lea, M. (1998). Breaching or building social boundaries? Side effects of Computer mediated communication. Communication Research, 25(6), 689-715.

Prothero, J. D., Parker, D. E., Furness III, T. A., \& Wells, M. J. (1995). Towards a robust, quantitative measure for presence. In Proceedings of the Conference on Experimental Analysis and Measurement of Situation Awareness (pp. 359-366).

Psotka, J. (1996). Immersive training systems: Virtual reality and education and training. Instructional Science, 23(5-6), 405-423.

Riva, G. (2008). From virtual to real body: virtual reality as embodied technology. Journal of CyberTherapy and Rehabilitation, 1(1), 1-22.

Riva, G., Montovani, F., \& Bouchard, S. (2014). Presence. In B. K. Wilderhold \& S. Bouchard (Eds), Advances in virtual reality and anxiety disorders (pp. 9-34). London: Springer.

Sala, M. (2016). Virtual Reality and Education: Overview Across Different Disciplines. In H. Choi., A. Dailey-Hebert., \& J. S. Estes (Eds), Emerging Tools and Applications of Virtual Reality in Education. Igi Global. DOI: 10.4018/978-1-4666-9837-6.ch001

Sas, C., \& O'Hare, G. M. P. (2003). Presence equation: An investigation into cognitive factors underlying presence. Presence: Teleoperators and Virtual Environments, 12(5), 523-537. DOI: $10.1162 / 105474603322761315$

Schubert, T. W. (2009). A new conception of spatial presence: once again, with feeling. Communication Theory, 19(2), 161-187.

Shin, D. H. (2017). The role of affordance in the experience of virtual reality learning: Technological and affective affordances in virtual reality. Telematics and Informatics, 34(8), 1826-1836.

Simon, V., Lanyi, C. S., \& Simon, L. (2005). Using virtual public transport for treating phobias. Journal of Endocrine Genetics, 4(3), 211-215.

Slater, M. (2002). Presence and the sixth sense. Presence: Teleoperators and Virtual Environments, $11(4), 435-439$.

Slater, M. (2009). Place illusion, and plausibility can lead to realistic behavior in immersive virtual environments. Philosophical Transactions of the Royal Society B: Biological Science, 364(1535), 3548-3557.

Salter, M., Brogni, A., \& Steed, A. (2003). Physiological response to breaks in presence: A pilot study. Presence, The 6th Annual International Workshop on Presence. Aalborg University, October 6-8, Denmark.

Slater, M., \& Steed, A. (2000). A virtual presence counter. Presence: Teleoperators and Virtual Environments, 9(5), 413-434.

Slater, M., \& Wilbur, S. (1997). A framework for immersive virtual environment (FIVE): speculations in the role of presence in virtual environment. Presence: Teleoperators and Virtual Environments, 6(6), 603-616.

Smart, L. J., Stoffregen, T. A., \& Bardy, B. G. (2002). Visually induced motion sickness predicted by postural instability. Human Factors, 44(3), 451-465.

Strickland, D., \& Chartier, D. (1997). EEG measurement in a virtual reality headset. Presence: Teleoperators and Virtual Environments, 6(5), 581-589.

Sutherland, I. (1968). A head-mounted three-dimensional display. Proceedings of the AFIPS Fall Joint Computer Conference (pp. 757-764). Washington D. C.: Thomson Books.

Tellegen, A. (1982). Brief manual for the differential personality questionnaire. Unpublished ms. University of Minnesota. Department of Psychology, Minneapolis.

Unoka, Z. (2010). Személyiségzavarok sématerápiája. In Perczel-Forintos, D., \& Mórotz, J. (Eds), Kognitív viselkedésterápia (pp. 689-737). Budapest: Medicina Könyvkiadó Zrt.

Yee, N., \& Bailenson, J. N. (2007). The Proteus effect: The effect of transformed selfrepresentation on Behavior. Human Communication Research, 33(3), 271-290. 
Yee, N., Bailenson, J. N., \& Ducheneaut, N. (2009). The Proteus effect: Implication of transformed digital self-representation on online and offline behavior. Communication Research, 36(2), 285-312.

Wiederhold, B., \& Wiederhold, M. (2008). Virtual reality for posttraumatic stress disorder and stress inoculation training. Journal of CyberTherapy and Rehabilitation, 1(1), 23-36.

Wirth, W., Hartmann, T., Böcking, S., Vorderer, P., Klimmt, C., Schramm, H., et al. (2007). A process model of the formation of spatial presence experiences. Journal of Media Psychology, 9(3), 493-525.

Witmer, B. G. \& Singer. M. J. (1998). Measuring presence in virtual environments: A presence questionnaire. Presence: Teleoperators and Virtual Environments, 7(3), 225-240.

\title{
PSYCHOLOGICAL MECHANISM IN COMPUTER GENERATED VIRTUAL REALITY: SPATIAL REPRESENTATION FEATURES
}

\author{
KÁLLAI, JÁNOS
}

The increased interest in health care- and educational activities carried out in virtual reality (VR) brought about the need to discuss certain psychological frameworks of interpretation concerning VR. My summary relies on special literature and partly on our own research work. It aims to define special terms such as immersion and presence that concentrates on presenting those mental models of $V R$, which comprise components of spatial representation. The overview introduces the concept of multisensory coherence, conscious being there, attachment to and detachment from the digital world, and different forms of affordances. In the Application chapter I primarily present a few of those VR-based processes that may be more widely applied in the future in health care and education in Hungary as well. The interest in digital education and health service has its own contradictions. There are fears that the personal contact between medical practitioners and clients or teachers and students will be lost. On the other hand, there is an increasing demand for the introduction of new methodologies, thus dialogues are inevitable. The more reliable and efficient application of the new processes may bear considerable mental and financial changes. I hope that my presentation will widen the demands concerning the application of digital technologies, and will draw attention on the need to establish technological and disciplinal infrastructure, which, after critical analysis, is able to alter certain - now contradictional - educational and health care processes. Introducing new VR methodologies should be a joint venture of research and practice.

Keywords: immersion, presence, multimodal integration, affordances, Proteus effect

A cikk a Creative Commons Attribution 4.0 International License (https://creativecommons. org/licenses/by/4.0) feltételei szerint publikált Open Access közlemény, melynek szellemében a cikk bármilyen médiumban szabadon felhasználható, megosztható és újraközölhetô, feltéve, hogy az eredeti szerzó és a közlés helye, illetve a CC License linkje és az esetlegesen végrehajtott módosítások feltüntetésre kerülnek. (SID_1) 